\title{
Research on the Secondary Development of Retired University Professors Based on the Background of Population Development Strategy
}

\begin{abstract}
Wenke $\mathrm{Bu}^{1, *}$ Meng'en Zhao ${ }^{1}$
${ }^{1}$ Shandong Guoying S-O-E Reform Institute, Ji'nan, Shandong 250014, China

*Corresponding author. Email: budufe@163.com

ABSTRACT

Based on the background of population development strategy, this paper uses grounded theory to take roots in the job interviews of two retired professors after returning to colleges and universities, and constructs a secondary development model for retired college professors. Studies have shown that family responsibilities, the "outdated theory" of retired professors, public and private schools, teachers, the establishment of rehiring platforms, and the acquisition of effective information are the key driving factors affecting the development of human resources for retired professors. In view of this, this article puts forward three countermeasures to build a platform for professors' re-employment, create information communication channels, and deepen college senior education, hoping to provide theoretical guidance and management inspiration for the secondary development of college retired professors.
\end{abstract}

Keywords: stochastic model checking, assume-guarantee reasoning, symmetric assume-guarantee rule,

learning algorithm, probabilistic automata

\section{INTRODUCTION}

In the report of the 19th National Congress of the Communist Party of China, Xi Jinping proposed that the implementation of the healthy China strategy should strengthen the study of population development strategy, actively respond to the aging of the population, build a policy system and social environment for the elderly, filial piety, and respect for the elderly, and accelerate the development of the cause of aging and industry. In order to cope with the problem of population aging and promote the comprehensive, coordinated and sustainable development of the cause of aging, the State Council proposed in the 2017 "Notice on Printing and Distributing the National Plan for the Development of Elderly Career and Pension System in the 13th Five-Year Plan" that the active role of the elderly should be exerted. To improve the development of the cause for the elderly, the elderly should be allowed to participate in social development, exert positive energy, and make new contributions. It is of important strategic significance for ensuring and improving people's livelihood, enhancing the sense of participation and happiness of the elderly, and realizing

*Project: Shandong Higher Education Talent Research Association Project (2019RK-14) (http://rcfz.sdufe.ecu.cn/) Shandong University of Finance and Economics 2018 Graduate Student Innovation Project (172107015) the stable and healthy development of the population.

Statistics from the sixth census show that the number of elderly people aged 60 and over in China is 178 million, which also indicates that China has been aging since 2010 [1]. So far, the aging of the population has shown increased growth. Situation [2]. About $70 \%$ of the retired professional and technical personnel aged 60 and above in China are in good health. Only after retirement does the elderly still have "waste heat" for about 10 years, but most of the retired professional and technical personnel do not participate in social practice. Professional skills and knowledge and experience have not been fully utilized, resulting in the idleness and waste of retired professional and technical personnel [3].

Among the talents with national senior professional and technical titles in China, universities and research institutes account for half of the total, and they are a treasure trove of valuable human resources. With the advent of the "double high period" for retirees in colleges and universities, whether it is a knowledgeable expert or a scholar with a profound cultural background, under the new trend of China's pension system and pension problems in the new era, there are some people with a sense of loss [4]. Retired talents from colleges and universities belong to highintellectual groups. After years of education or 
management work, they have incomparable advantages with other elderly or middle-aged and young people in terms of ideological and political, knowledge and experience, personality prestige, and human cost [5], as a society The development of important resources that can be relied on, the development and utilization of retired professional and technical talents in colleges and universities has the dual strategic significance of realizing their life value and effective use of resources. At the same time, as an important carrier of the "workbased pension" model, it provides a reference for other industries in alleviating social pension pressure and improving the pension model, and has become a successful model of new breakthroughs in the pension model [6]. Fully understanding and exerting the value of the secondary development of retired university professors is an important part of the implementation of the active aging strategy and the strategy of strengthening the country with talents. It is also an inevitable requirement for the implementation of the strategy of strengthening the school with talents and creating a harmonious campus [7]. Allowing retired university professors to exert positive energy and make new contributions has the dual practical significance of realizing their life value and effective use of resources.

\section{LITERATURE REVIEW}

\section{A. Definition of basic concepts}

Retired talents are collectively referred to as "silver" talents" [8]. "Silver talents" are collectively referred to as people with senior professional titles and skills in the human resources of the elderly, especially those elites with strong intellectual capital and strong professional skills in the human resources of the elderly. . Retired talents include retired talents and retired talents. Retired talents refer to those who meet the resignation and recuperation system. Retired talents refer to the talents who meet the retirement standards, the employer dismisses the labor obligation of the laborer, and begins to enjoy the pension insurance benefits [9]. This article defines retired professors as university professors who have reached retirement age, retired from their original positions, and no longer do their original jobs but can continue to work in related fields. Retired professors have the characteristics of capital, timeliness, accumulation and diligence and self-consciousness. They are huge in number and have obvious advantages. They are an important source of resource development for the elderly [10]. "Second development of retired professors" mainly refers to the re-exploitation of elites with strong knowledge capital and strong professional skills in the human resources of retired professors in colleges and universities, and give full play to their knowledge, technology, experience and other potentials to serve the school society and create wealth.

\section{B. Development status of retired university professors}

Judging from the current management status of "the old being able to do something" for retired professors in colleges and universities, the difference in understanding of "the old being able to do something", the standardization of the system, the shortage of platforms and information channels, have severely restricted the development of university professors. [5]. From the perspective of the lifestyle of retired college talents, there are four main life states: self-cultivation, inactivity, enthusiasm for public welfare, and reemployment. The retired college retirees account for a very small proportion, and most retired professors are in I don't know how to arrange my life after retirement [11]. From the perspective of the mental health of university professors after retirement, university retirees with high-level education have serious mental health problems. Sensation of aging, loneliness, and loss are their main psychological characteristics.

\section{Factors affecting the secondary development of retired university professors}

1) Personal factors: Some college retired professional and technical talents have reached the retirement age, because they pay attention to health preservation, live a regular life and actively exercise, most of the young people are in good physical condition [12] and are still energetic [13], for The human resources development of retired university professors laid the foundation. A strong physique is a necessary prerequisite for the elderly to continue to engage in production work, and personal ability also plays a key role in the in-depth development of human resources for the elderly [14].

2) Family factors: With the relaxation of the national childbirth policy, the family model has gradually changed to a "four, two, two" model, which means that a couple will support 4 elderly people and 2 children [15], which is burdened by young laborers. The aggravation has led to frequent family conflicts and the continuous weakening of family security functions, which has seriously affected family interpersonal harmony. The retirement fee of the elderly is not high, and the life pressure and family burden after retirement affect the willingness of retired talents to reemployment [13].

3) Social prejudice: "Retired elderly people are social burdens." This "age discrimination" causes psychological harm to retired elderly people and severely hits the enthusiasm of retired professionals to continue participating in social activities. There are ideological and cognitive misunderstandings in the effective development and utilization of retired professional and technical personnel: First, the theory 
of "grabbing jobs". Our country is in a buyer's market where supply exceeds demand, and it is difficult for young people to find ideal jobs. The secondary development of retired professional and technical talents not only poses obstacles to the employment and career development of young people, but also an embarrassing situation in which the elderly and young people grab a bowl of rice together. Second, the obsolescence theory. The thinking of the elderly is derailed from the times, and knowledge and experience can no longer meet the needs of social and economic development [16]. Retired elderly people basically lack the education link, lack enterprising spirit and innovative spirit, and have no passion for work, so they should take care of their lives [17].

\section{The significance of the secondary development of retired university professors}

1) Realizing their own value: Some young people with strong vocational skills have a strong desire to reemploy, and they hope to maximize their own value [18]. The Chinese Academy of Sciences has 67 hospitals, institutes, and centers, and has 3,289 retired people who are physically and mentally healthy. Among the retired professionals in our country, experts and scholars and leaders from all walks of life account for a lot of proportions. Their technical experience, knowledge reserves, and contacts can continue to create personal value for the organization and society, even for consulting. The work can also be of great value [19]. These elderly people reinvest in their favorite jobs, give play to their unique advantages and solve special problems, not only to achieve "the elderly have something to do", but also to the physical and mental health of retirees [20].

2) It is good for physical and mental health and gain a sense of belonging to the organization: Retired talents from colleges and universities are a model of caring about society and the people. They have dedicated their lives to colleges and universities, and their sense of loss and loneliness after retirement will cause their psychological imbalance and emotional instability. Exploring the secondary development of retired professors in colleges and universities under the "Silver Wave", allowing retired professors to maintain a certain working status, actively participate in the organization of the original unit, and increase the social participation of retired professors, which can significantly improve their subjective well-being and Organizational belonging [21] is an effective way to prevent mental disorders and mental aging of retired university professors. When young professors come into contact with new environments and meet new colleagues, they can not only open up interpersonal communication, enhance psychological satisfaction and organizational belonging, but also actively adjust their mentality when facing retirement, and avoid irritability, depression, irritability, etc. caused by retirement. Disease" [22]. The development of human resources for retired university professors is an extension and development of the "ageing" of university retired talents. It not only promotes the physical and mental health of the elderly in universities, but also promotes the effective implementation of university talent strategies [23].

3) Research methods and data sources: Social prejudice: "Retired elderly people are social burdens." This "age discrimination" causes psychological harm to retired elderly people and severely hits the enthusiasm of retired professionals to continue participating in social activities. There are ideological and cognitive misunderstandings in the effective development and utilization of retired professional and technical personnel: First, the theory of "grabbing jobs". Our country is in a buyer's market where supply exceeds demand, and it is difficult for young people to find ideal jobs. The secondary development of retired professional and technical talents not only poses obstacles to the employment and career development of young people, but also an embarrassing situation in which the elderly and young people grab a bowl of rice together. Second, the obsolescence theory. The thinking of the elderly is derailed from the times, and knowledge and experience can no longer meet the needs of social and economic development [16]. Retired elderly people basically lack the education link, lack enterprising spirit and innovative spirit, and have no passion for work, so they should take care of their lives [17].

\section{E. The significance of the secondary development of retired university professors}

1) Realizing their own value: Some young people with strong vocational skills have a strong desire to reemploy, and they hope to maximize their own value [18]. The Chinese Academy of Sciences has 67 hospitals, institutes, and centers, and has 3,289 retired people who are physically and mentally healthy. Among the retired professionals in our country, experts and scholars and leaders from all walks of life account for a lot of proportions. Their technical experience, knowledge reserves, and contacts can continue to create personal value for the organization and society, even for consulting. The work can also be of great value [19]. These elderly people reinvest in their favorite jobs, give play to their unique advantages and solve special problems, not only to achieve "the elderly have 
something to do", but also to the physical and mental health of retirees [20].

2) It is good for physical and mental health and gain a sense of belonging to the organization: Retired talents from colleges and universities are a model of caring about society and the people. They have dedicated their lives to colleges and universities, and their sense of loss and loneliness after retirement will cause their psychological imbalance and emotional instability. Exploring the secondary development of retired professors in colleges and universities under the "Silver Wave", allowing retired professors to maintain a certain working status, actively participate in the organization of the original unit, and increase the social participation of retired professors, which can significantly improve their subjective well-being and Organizational belonging [21] is an effective way to prevent mental disorders and mental aging of retired university professors. When young professors come into contact with new environments and meet new colleagues, they can not only open up interpersonal communication, enhance psychological satisfaction and organizational belonging, but also actively adjust their mentality when facing retirement, and avoid irritability, depression, irritability, etc. caused by retirement. Disease" [22]. The development of human resources for retired university professors is an extension and development of the "ageing" of university retired talents. It not only promotes the physical and mental health of the elderly in universities, but also promotes the effective implementation of university talent strategies [23].

\section{RESEARCH METHODS AND DATA SOURCES}

\section{A. Definition of basic concepts}

Grounded theory is one of the more popular qualitative research methods at present, and it is a method of establishing theories from the bottom up. This study uses grounded theory to explore the factors that affect the secondary development of retired university professors and development strategies. The text data obtained through in-depth interviews is used to openly code the original data; secondly, it conducts main axis coding to discover and establish conceptual categories. Various connections; finally, selective coding is performed to connect the core category with other category categories.

\section{B. Sample source}

Grounded theory requires the interviewee to have a certain understanding and knowledge of the research problem. Before conducting the interview, he should first arrange a time with the interviewee and inform the interview subject before conducting the interview. According to the definition of retired professors, this article selects two retired professors from Shandong University of Finance and Economics as the interviewees. Among them, interviewee $\mathrm{A}$ is a female professor who is 69 years old, and B is a male professor who is 65 years old. The two university professors were hired by the school as teaching supervisors before they retired, and they have been working in the teaching supervision group after their retirement. They have not completely withdrawn from the teaching supervision group until recently. Each interviewee was interviewed for 30 to 40 minutes. With the consent of the interviewee, we recorded the interview and systematically organized the recording files to form an original interview record of more than 4,600 words. For interview records, open coding, spindle coding and selective coding are carried out through the exploratory technique of grounded theory. The entire coding process continues to refine and update the influencing factors and development strategies that affect the secondary development of retired university professors, until it reaches saturation.

\section{Category refinement and model construction}

Open coding: Open coding is the process of conceptualizing and categorizing the original data. The original data is broken up, crushed, and recombined with related concepts or concepts in the original sentence. The main operating steps of open coding are labeling, conceptualization, and categorization in sequence. First, a large amount of original data is initially decomposed (labeled), and then classified by defining phenomena. Through continuous comparison between phenomena, the performance can be summarized. Represent the concept of phenomenon, and finally the summarized concept is further refined and summarized into the category. In the process of open coding, researchers always have an open mind to code the materials according to their own state, avoiding personal bias and the influence of original research in the literature. The specific coding process is as follows.

1) Labeling: Firstly, the interview recordings of the two professors were transcribed into text data, and then analyzed sentence by sentence, then labeled, that is, to define the phenomenon, and use "(a)" to refer to each analysis unit, and finally 118 declarative sentences were obtained. Take interviewee A as an example, according to the text, we sort out the initial declarative sentence, and some analysis results are shown in "Table I". 
TABLE I. CONCEPTUALIZING EXCERPTS

\begin{tabular}{|c|c|c|c|c|}
\hline & Initial statement & conceptualization & Initial statement & conceptualization \\
\hline \multirow{5}{*}{$A$} & $\begin{array}{l}\text { (a18) Did not take the } \\
\text { initiative to grab the jobs of } \\
\text { young people }\end{array}$ & $\begin{array}{l}\text { (aa18)Influence } \\
\text { traditional ideas }\end{array}$ & $\begin{array}{l}\text { (a23) No need to grab the job } \\
\text { of young people }\end{array}$ & $\begin{array}{l}\text { (aa23)Influence of traditional } \\
\text { ideas }\end{array}$ \\
\hline & $\begin{array}{l}\text { (a19) Unwilling to grab } \\
\text { young people }\end{array}$ & $\begin{array}{l}\text { (aa19) Influence of } \\
\text { traditional ideas }\end{array}$ & $\begin{array}{l}\text { (a27) There is no need to } \\
\text { actively ask for rehiring }\end{array}$ & (aa27)Rehiring motivation \\
\hline & (a20) Workload & (aa20) Workload & $\begin{array}{l}\text { (a28) Passive acceptance of } \\
\text { rehiring }\end{array}$ & (aa28)Rehiring initiative \\
\hline & (a21) Peaceful life & (aa21) Peaceful life & (a29) Self-knowledge & (aa29) Personal awareness \\
\hline & $\begin{array}{l}\text { (a22)Salary and welfare } \\
\text { satisfaction }\end{array}$ & $\begin{array}{l}\text { (aa22)Salary } \\
\text { benefits }\end{array}$ & $\begin{array}{l}\text { (a30) Outstanding personal } \\
\text { performance }\end{array}$ & (aa30) Individual ability \\
\hline
\end{tabular}

2) Conceptualization: Firstly, 118 initial declarative sentences were screened, and the ones that were not related to the research content and the semantically unclear, such as "I came from Shanda in 1992, and now I was transferred to Shancai in 1992" and other sentences, finally left 63 sentences The declarative sentences with clear semantics and closely related to the research content further summarized 63 concepts, analyzed and compared them, and finally defined 37 different concepts. The concept "(aan)" represents the conceptualization of the initial statement "(an)". All the results of the conceptual analysis are shown in "Table II".

\section{TABLE II. CONCEPTUALIZING EXCERPTS}

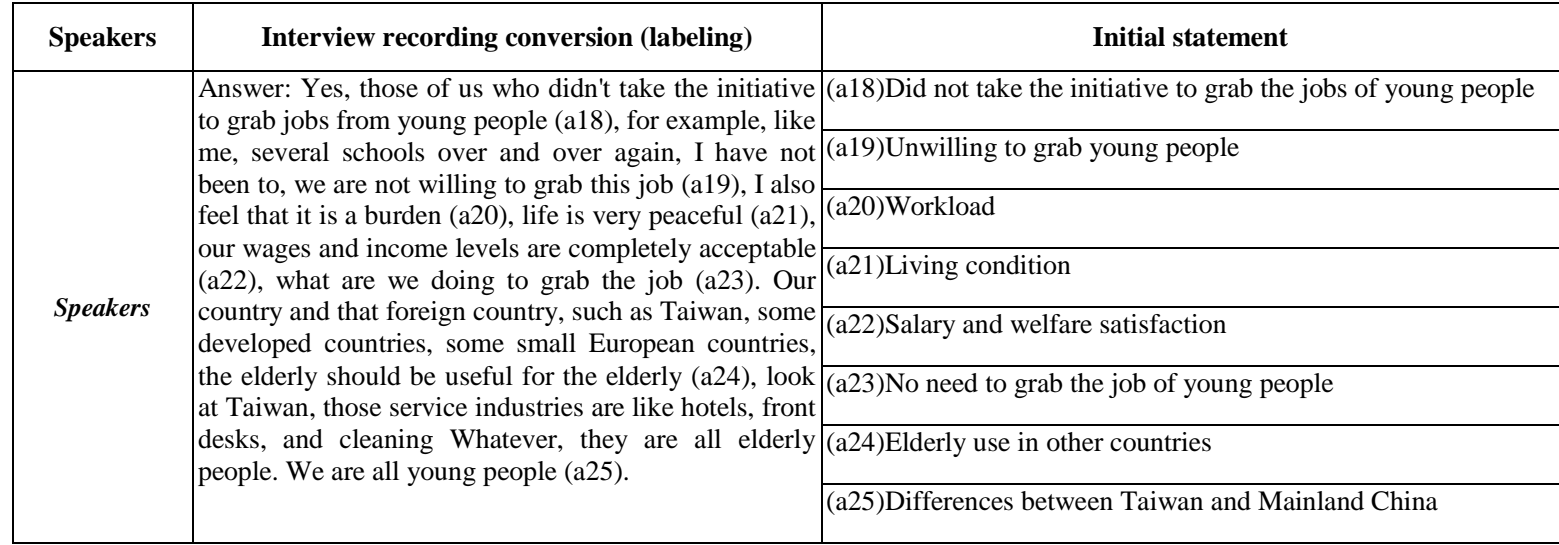

3) Categorization: Since the conceptualization process is still carried out separately according to the content of the two interviewees' conversations, there are many repetitions in it. In the process of categorization, it is no longer divided into objects, but all concepts are broken up and mixed, while repeated comparisons and further categorization, and finally 18 categories are obtained, namely (A1-A18): own ability, health status , Energetic, family responsibilities, social prejudice, school conditions, work status, learning status, reemployment attitude, life status, work platform, salary and benefits, education and training, communication channels, self value, personal achievement, organizational belonging, personal achievement, physical and mental health. The nature of the category and the dimension of the category can be embodied by the interpretation of the category. For example, the status of a school refers to the degree of standardization of the school, whether the teaching staff is strong, the establishment of a platform for the re-employment of school professors, and the creation of information communication channels. The specific categorization process and the nature and dimensions of the category are shown in "Table III". 
TABLE III. CATEGORIZATION ANALYSIS

\begin{tabular}{|c|c|c|c|}
\hline Categorization & Category name & Categorical nature & Nature dimension \\
\hline \multirow{2}{*}{$\begin{array}{c}\text { Personal awareness } \\
\text { Experienced and } \\
\text { taught }\end{array}$} & \multirow{2}{*}{$\begin{array}{l}\text { (A1) } \\
\text { capability }\end{array}$} & \multirow{2}{*}{$\begin{array}{l}\text { How much one's own ability, rich } \\
\text { experience }\end{array}$} & many-—less \\
\hline & & & rich-—Not rich \\
\hline $\begin{array}{l}\text { Physical conditions } \\
\text { Age pressure } \\
\end{array}$ & $\begin{array}{lll}\text { (A2) } & \text { State of } \\
\text { health } & & \\
\end{array}$ & Physical health & health-—Unhealthy \\
\hline $\begin{array}{l}\text { Lack of energy } \\
\text { Full of energy }\end{array}$ & $\begin{array}{ll}\text { (A3) Full of } \\
\text { energy }\end{array}$ & Energetic & $\begin{array}{l}\text { abundant }-- \text { Not } \\
\text { enough }\end{array}$ \\
\hline $\begin{array}{l}\text { Family responsibility } \\
\text { Family burden }\end{array}$ & $\begin{array}{l}\text { (A4) Family } \\
\text { Factors }\end{array}$ & Responsibility to the family & $\begin{array}{l}\text { Responsible } \\
\mathrm{L}--\mathrm{No} \text { sense of } \\
\text { responsibility }\end{array}$ \\
\hline \multirow{2}{*}{$\begin{array}{l}\text { Influence of } \\
\text { traditional ideas }\end{array}$} & \multirow{2}{*}{ (A5) Social bias } & $\begin{array}{l}\text { Influenced by the elderly grabbing } \\
\text { the jobs of the young }\end{array}$ & \multirow{2}{*}{$\begin{array}{l}\text { Small impact }- \text { big } \\
\text { influence }\end{array}$} \\
\hline & & $\begin{array}{l}\text { Influenced by the "outdated theory" } \\
\text { of veterans }\end{array}$ & \\
\hline \multirow{4}{*}{$\begin{array}{l}\text { Unit standardization } \\
\text { Unit nature Teacher } \\
\text { force Platform } \\
\text { construction } \\
\text { Information channels }\end{array}$} & \multirow{4}{*}{$\begin{array}{l}\text { (A6) School } \\
\text { conditions }\end{array}$} & \multirow{4}{*}{$\begin{array}{l}\text { The degree of standardization of the } \\
\text { school, the strength of teachers }\end{array}$} & $\begin{array}{lll}\text { specification } & - & - \\
\text { irregular } & & \\
\end{array}$ \\
\hline & & & $\begin{array}{l}\text { Strong teachers }-- \\
\text { Weak teachers }\end{array}$ \\
\hline & & & $\begin{array}{l}\text { Many platforms }-- \\
\text { Less platforms }\end{array}$ \\
\hline & & & $\begin{array}{l}\text { Many channels-- Less } \\
\text { channels }\end{array}$ \\
\hline \multirow{2}{*}{$\begin{array}{l}\text { Working polarity } \\
\text { Workload } \\
\text { Work hard }\end{array}$} & \multirow{2}{*}{$\begin{array}{l}\text { (A7) } \\
\text { status }\end{array}$} & \multirow{2}{*}{$\begin{array}{l}\text { Work motivation } \\
\text { Seriousness of work }\end{array}$} & $\begin{array}{l}\text { High motivation }-- \\
\text { Low motivation }\end{array}$ \\
\hline & & & serious - Not serious \\
\hline $\begin{array}{c}\text { Continue studying } \\
\text { Active learning }\end{array}$ & $\begin{array}{ll}\text { (A8) Learning } \\
\text { Status }\end{array}$ & Learning initiative & initiative - Not active \\
\hline $\begin{array}{c}\text { Rehiring motivation } \\
\text { Rehiring initiative } \\
\text { Rehiring willingness }\end{array}$ & $\begin{array}{l}\text { (A9) Rehiring } \\
\text { attitude }\end{array}$ & $\begin{array}{l}\text { Rehiring willingness is strong or } \\
\text { weak }\end{array}$ & Strong-—weak \\
\hline
\end{tabular}

4) Spindle coding: Spindle coding is a process of association decoding, that is, establishing various connections between categories according to the canonical model of "causal conditions $\rightarrow$ phenomenon $\rightarrow \quad$ context $\rightarrow$ intermediary conditions $\rightarrow$ actions/interactions $\rightarrow$ results". The main four tasks of the main axis coding: one is to determine the attributes and scope of the main category; the other is to identify the various conditions, actions/interactions and results of the event, and to associate them with a social phenomenon; the third is to explain the main category and the category The fourth is to find the correlation between the main categories. In this research, the following four main categories are summarized based on the 18 categories derived from categorization: development factors, development status, development countermeasures, development results, and each main category and its corresponding category are obtained, as shown in "Table IV". According to the specific situation of the research problem, the model model "causal condition $\rightarrow$ phenomenon $\rightarrow$ action/interaction $\rightarrow$ result" is simplified, and the relationship between the various categories of connection is shown in "Fig. 1". 
TABLE IV. THE MAIN CATEGORY FORMED BY THE SPINDLE CODE

\begin{tabular}{|c|c|c|}
\hline Category & $\begin{array}{c}\text { Main } \\
\text { category }\end{array}$ & Main category connotation \\
\hline $\begin{array}{l}\text { (A1) Personal factors (A2) } \\
\text { Family factors } \\
\text { (A3) Social factors (A4) } \\
\text { School factors }\end{array}$ & $\begin{array}{l}\text { Developme } \\
\text { nt factors }\end{array}$ & $\begin{array}{l}\text { The factors affecting the development of human resources of } \\
\text { retired university professors mainly include personal factors, } \\
\text { family factors, social factors, and school factors. }\end{array}$ \\
\hline $\begin{array}{l}\text { (A5) Working status (A6) } \\
\text { Learning status } \\
\text { (A7) Re-employment } \\
\text { attitude (A8) Life status }\end{array}$ & $\begin{array}{l}\text { Developme } \\
\text { nt status }\end{array}$ & $\begin{array}{l}\text { The attitudes of retired university professors on human } \\
\text { resource development and their work, study and living } \\
\text { conditions after reappointment }\end{array}$ \\
\hline $\begin{array}{l}\text { (A9) Work platform } \\
\text { (A10) Education and } \\
\text { training } \\
\text { Communication channels }\end{array}$ & $\begin{array}{l}\text { Developme } \\
\text { nt strategy }\end{array}$ & $\begin{array}{l}\text { The school's actions and countermeasures for the } \\
\text { development of human resources of retired university } \\
\text { professors include building a working platform, conducting } \\
\text { training and education, and building information } \\
\text { communication channels }\end{array}$ \\
\hline $\begin{array}{l}\text { (A12) Self-worth (A13) } \\
\text { Personal achievement } \\
\text { (A14) Organizational } \\
\text { affiliation (A15) Physical } \\
\text { and mental health }\end{array}$ & $\begin{array}{l}\text { Developme } \\
\text { nt results }\end{array}$ & $\begin{array}{l}\text { The development of human resources for retired university } \\
\text { professors will make them "useful for old age", but will also } \\
\text { bring a sense of personal accomplishment and a sense of } \\
\text { belonging to the organization, as well as beneficial to physical } \\
\text { and mental health }\end{array}$ \\
\hline
\end{tabular}

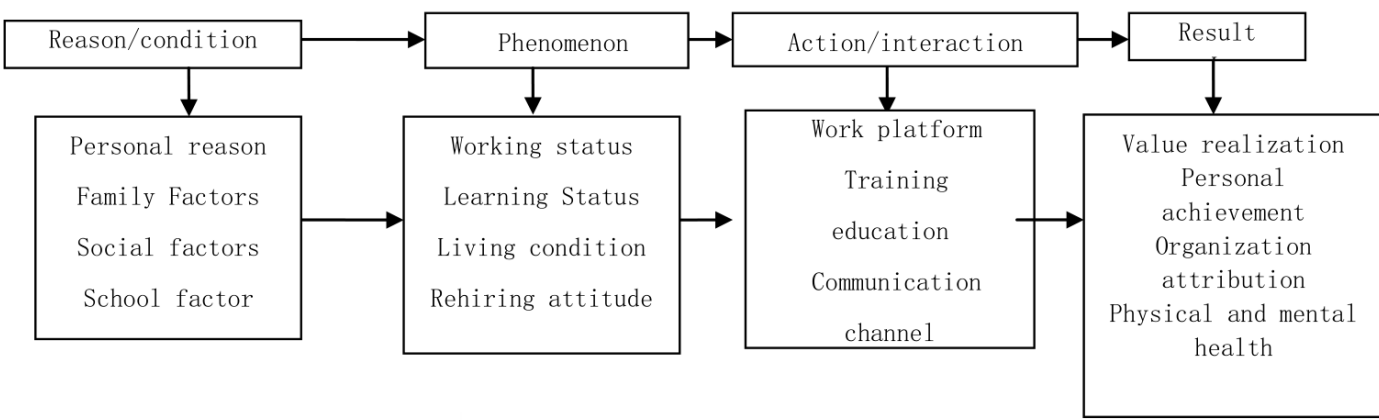

Fig. 1. Canonical model.

5) Selective coding: Selective coding refers to selecting the core categories from the main categories of discovery and establishment, using the core categories as the "story line", establishing the relationship between the core categories and other categories, and constructing a new theoretical framework to explain each category The connection, influence and causality between. This article extracts the core category "secondary development of retired university professors" to summarize the issues that this research focuses on. This core category shows that the issue of secondary development of retired university professors begins with the exploration of factors that affect the development of human resources of retired university professors, and analyzes the willingness and current status of secondary development of university retired professors. The actions and countermeasures of the secondary development ultimately make university professors "useful for the elderly", but also benefit their physical and mental health. The entire development system should be cyclically and continuously moving forward. New problems will continue to arise in the exploration and implementation, and new countermeasures should be adopted.

6) Model interpretation: Studies have shown that there are many factors that affect the secondary development of retired university "Fig. 2". 


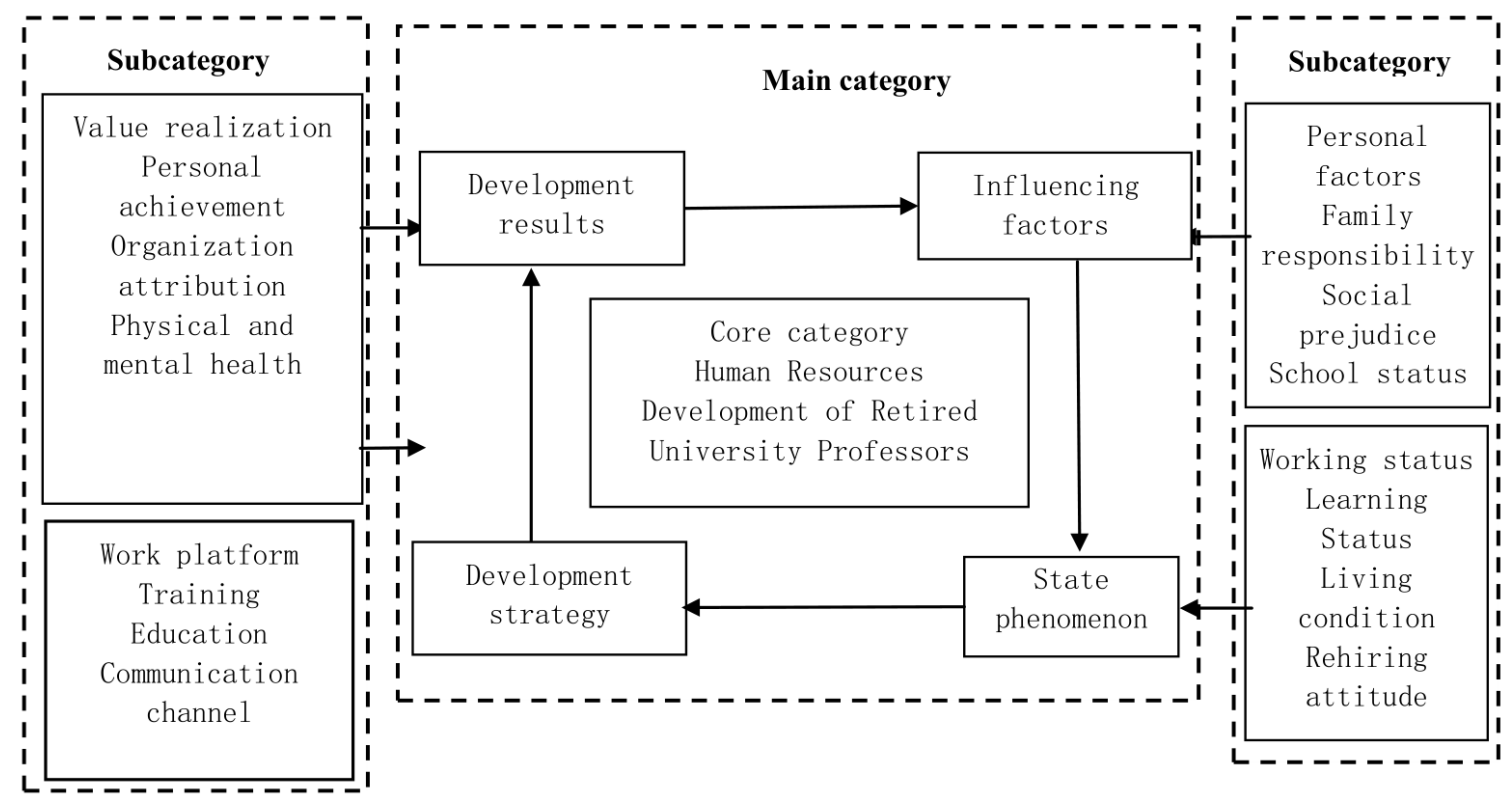

Fig. 2. Selective coding.

Professors, including personal factors (own ability, energy, physical health), family factors (family responsibilities, family burden), and social factors (traditional prejudice "job-grabbing theory", "outdated theory"), school factors (the school is public and private, the teaching staff, the establishment of rehiring platforms, the creation of communication channels). Among them, family responsibilities, the "outdated theory" of retired professors, the public and private nature of the school, the strength of teachers, the reasonable establishment of the school's rehiring platform, and the timeliness of information communication are the key driving factors for the secondary development of retired professors. Establishing a platform for re-employment of professors, creating information communication channels, and strengthening the education and training of university professors can specifically solve the secondary development of retired university professors.

\section{DISCUSSION OF RESULTS: ANALYSIS OF FACTORS AFFECTING THE SECONDARY DEVELOPMENT OF RETIRED UNIVERSITY PROFESSORS}

According to the grounded theory, the main category of "internal factors" that influence the secondary development of retired university professors includes three sub-categories of personal ability, energetic, and physical health. Good health is a prerequisite for the secondary development of retired professional and technical personnel. Good health means the higher the value and degree of development. The lack of energy and physical strength of retired university professors due to the decline in physical function makes it difficult for them to join the social practice after retirement. In the interview, although the two retired professors are entering the aging stage, they are in good physical condition and energetic, and they are willing to invest in the construction of the school due to their emphasis on health preservation, regular life and active physical exercise. A strong physique is a necessary prerequisite for the elderly to continue to engage in production work, and personal ability plays a decisive role in the in-depth development of human resources for the elderly [12]. In the interview, two retired professors have worked in universities for decades and have rich experience in teaching and scientific research. They do not want to waste their knowledge and experience, do not want to simply break away from their jobs, and have a strong desire to return to employment. desire.

The main category of "external factors" affecting retired professional and technical talents in colleges and universities includes three sub-categories of family factors, social factors and school factors. With the country's relaxation of the childbirth policy, the family model has gradually shifted to a "four, two, two" model, and the burden of raising young laborers has further increased. Retired professors who were separated from the ministry were unable to continue to work in schools because of "child care". The rapid economic growth has led to an increase in the consumption level of residents, and the old people's own retirement funds are not high. When facing the life pressure and family burdens after retirement, they are willing to go to work units for reemployment [13]. In the interview, the retired professor stated that although the pension and salary after re-employment are not very 
high, it is sufficient to supplement personal life and there is not much financial difficulty in the family. Therefore, family burden is not the main factor affecting the human resources development of the retired professor.

There are some misunderstandings in the ideological understanding of the effective development and utilization of human resources about retired university professors: First, the theory of "grabbing jobs". Our country is in a buyer's market where supply exceeds demand, and it is difficult for young people to find ideal jobs. The development of human resources for retired professors not only creates obstacles to the employment and career development of young people, but also creates an embarrassing situation of grabbing a "bowl of rice" with young people. According to the indepth interviews with the two professors, the reemployment supervision work is the work assigned by the school. The supervisory position is indispensable and indispensable for young talents and unwilling to do it. It is by no means "white-haired people grab black hair". People's rice bowl". Second, the "outdated theory". The lack of a lifelong education system and the failure to incorporate the old-age education legislation into the overall school development plan resulted in the lack of education resources for the elderly and the basic lack of education links [17], which eventually led to the derailment of retired professors' thinking and the times, and their knowledge and experience could not adapt to social economic development Need [16], which seriously affects the development of human resources for retired university professors.

School factors play a pivotal role in the development of human resources affecting retired university professors. From the perspective of the nature of the school, after retiring professors, they are very concerned about whether their rehiring unit is public or private. Private institutions mean tired work and lack of freedom. Most female professors will not choose to re-employ. From the perspective of the school's teaching staff, the school's teaching staff is strong, and there is no shortage of scientific research and teaching talents. The phenomenon of "more monks and porridge" appears, and the opportunities for professor development are small.

The lack of a functioning platform and effective information communication channels has led to information asymmetry between talent supply and market demand, which has seriously affected the secondary development of retired university professors. From the perspective of the school's platform, research, supervision, teaching and other job platforms are the reemployment platform for most university professors, and most retired professors are willing to return to their original jobs to engage in teaching, management and other tasks. From the perspective of the establishment of information communication channels, most of the retired professors lack timely knowledge of school information, and are no longer familiar with the management and teaching status of the school, which seriously affects the smooth progress of their later rehiring work.

\section{CONCLUSION}

Through the above analysis, we have summarized some countermeasures for secondary development of retired colleges and universities. In the analysis of factors affecting the development of human resources for retired university professors, the main influencing factors include family responsibilities, social prejudice "outdated theory", the nature of the school, the strength of teachers, the establishment of school platforms, and the creation of information communication channels. This article mainly aims at the social prejudice, the lack of corresponding education of the age of retired professors, the lack of a platform to display their personal talents, and the difficulty in understanding the current teaching and management changes in three aspects and provide corresponding countermeasures. We should improve the secondary development of retired professional and technical talents by strengthening education and training, building work platforms, and creating information communication channels.

\section{References}

[1] Lu Lin, Lan Zhuhong. Analysis of the influencing factors of the employment willingness of the urban elderly in China-based on the data of the 2010 China urban and rural elderly population tracking survey [J]. Northwest Population, 2015(4): 90-95.

[2] Huang Zhenbang. The Utilization and Development of "Silver Talents" - Analysis on the countermeasures of enterprises to develop the human resources of the elderly[J]. Enterprise Reform and Management, 2014 (13): 65+84.

[3] Sun Ping, Peng Qingyun. The experience and enlightenment of the development of human resources in the elderly under the background of population aging $[\mathrm{J}]$. China Human Resources Development, 2016(21): 81-84.

[4] Han Lihua, Liu Xiaosen. Analysis on the management and service of retirement in colleges and universities [J]. Education Teaching Forum, 2017 (38): 15-16.

[5] Wang Faming. The status quo and countermeasures of "the old do something" for retired people in colleges and universities[J]. Human Resource Management, 2018(1): 367-368.

[6] Gou Junping. On the development and management of retired talents in colleges and universities[J]. China Electric Power Education, 2008 (15): 204-206.

[7] Li Junying, Wang Cunxi, Zhang Juan, et al. Research on the Development and Utilization of Human Resources of Retired Professors of North China University of Science and Technology[J]. Journal of North China University of Science and Technology, 2014(10):118-121.

[8] Chen Xingquan. Strengthening thought leadership and developing "silver" talents-exploration and practice in Xiaoshan 
District, Hangzhou [J]. Operation and Management, 2016(4): 47-50.

[9] Zhang Yanping, Pang Yongshi, Ruan Peishan. The construction of a platform for re-exposing the social value of knowledgebased retired talents: Taking the construction of the Silver Talent Network as an example [J]. Journal of Guangzhou University: Social Science Edition, 2013, 12(8): 64-69.

[10] Yu Mingda. Actively implement the "silver talent" redevelopment strategy-fully tap the retired senior talent resources in Henan[J]. Journal of Xinyang Agriculture and Forestry College, 2013, 23(4): 35-40.

[11] Chen Yalan. Talking about how to do a good job in the management and service of retired veteran cadres in the new era[J]. Chinese Market, 2011(52):117-118.

[12] Liu Qing, Ban Xiaona. Analysis of the development strategy of the human resources of the young and old in urban communities[J]. Theoretical Observation, 2014(9): 83-84.

[13] Shao Jie. Development and management of retired professional and technical personnel resources in colleges and universities[J]. China Economic and Trade Guide, 2016(14): 4243.

[14] Zhao Bo. Some thoughts on the in-depth development of human resources for the elderly[J]. Chinese Market, 2014(24): 70-71.

[15] Ni Qing, Sun Lili, Wang Chengcheng, et al. Research on the Development of the Human Resources Market for the Elderly in my country - Based on the Analysis of the Differences in Organizational Identity [J]. China Human Resources Development, 2015(19): 72-79.

[16] Li Da, Hu Hongxia, Wang Juncheng. Exploration and analysis of the development and utilization of human resources of the young and old people in Yunnan Province-Based on the background of population aging $[\mathrm{J}]$. Journal of Changchun University, 2015(1): 42-45..

[17] Zhang Fen. Delaying retirement, how to make good use of the human resources of the elderly[J]. Enterprise Management, 2016(4): 31-33.

[18] Zhao Lei, Yang Jing. Exploration and analysis of the development of human resources of the elderly in my country under the background of population aging[J]. Inner Mongolia Science Technology and Economy, 2017(8): 30-31.

[19] Xu Xuerong, Yin Yiyi. Exploration and analysis of human resource development in agricultural scientific research institutions under the new population situation[J]. China Management Information Technology, 2018(4):74-75.

[20] Chen Siyi. Research on the development of the human resources of the elderly in my country under the background of population aging[J]. Times Finance, 2016(6): 92-93.

[21] Yang Hutao, Tian Ying. The shortage of human resources and the exploration of "Silver Age" human resources development: Taking Wuhan as an example [J]. Aging Science Research, 2014(6).

[22] Li Song. Research on the development of human resources of young and old people by enterprises under the silver wave[J]. Human Resource Management, 2016(2): 29-31.

[23] Han Lihong. Thoughts on the reuse of retired professional and technical personnel[J]. Hebei Academic Journal, 2014 (2):162164.

[24] Wang Fa. The status quo and countermeasures of "the elderly have something to do" for retired people in colleges and universities[J]. Human Resources Management, 2018(1):367368. 